UDK 314.116-026.24(4+497.5)

\title{
Demografski slom Hrvatske i Europe
}

\author{
Žarko Šperanda*, Mirjana Radan**, Željko Rakošec***
}

\begin{abstract}
Sažetak
Obiteljski profil stanovništva Republike Hrvatske bitno se promijenio. Od skladne obiteljske atmosfere uz pravovremenost braka i djece, deagrarizacijom i urbanizacijom obitelj je izgubila tradicionalan izgled. Prihvaćanjem razdvajanja neraskidivosti bračnog čina i rađanja otvara se prostor manipulacijama s plodnošću, kontracepcijom i medicinski pomognutom oplodnjom (MPO). Time je omogućena odgoda braka i rađanja za biološki već neprikladno vrijeme. Stvorena je anti-obiteljska atmosfera. Slične promjene događaju se u većini Europskih zemalja.

Ključne riječi: demografija, smanjena plodnost, neplodnost, kontracepcijski mentalitet, obiteljski stav
\end{abstract}

\section{Uvod}

Prije četrdesetak godina izgled obitelji bio je bitno drugačiji negoli je to danas. Kućanstvo je uglavnom imalo trogeneracijski koncept, kojim se definirala tradicionalna obitelj ruralnih krajeva. Ona bi u sebi sadržavala više generacija jedne obitelji, koje bi se međusobno pomagale i različitim funkcijama ispunjavale potrebne zadaće. Takav koncept prevladavao je uglavnom do 70-tih godina 20. stoljeća. U tim okolnostima i planiranje obitelji bilo je mnogo ozbiljnije shvaćeno negoli danas. Neposredno nakon završenog školovanja bilo kojeg stupnja zasnivala se obitelj s ciljem što ranijeg rađanja djece. Tako se htjelo izbjeći moguće kasnije nadolazeće bolesti koje bi remetile zakašnjele planove. S obzirom na to da se nije čekalo na stambeno zbrinjavanje da bi se zasnovala obiteljska zajednica, sve se događalo usporedo (zapošljavanje, brak, djeca, rješavanje stambenog pitanja). Pri tom su svi članovi obitelji pomagali mladomu bračnomu paru, koji je u početku najčešće živio u zajednici s roditeljima. Budući da se znalo kako

* $\quad$ Mr. sc. Žarko Šperanda, Dom Zdravlja Slavonski Brod. Adresa: Borovska 7, 35000 Slavonski Brod, Hrvatska. E-pošta: sperandazarko@gmail.com

** Dr. sc. Mirjana Radan, Županijska Bolnica Čakovec. Adresa: I.Gorana Kovačića 1e, 40000 Čakovec, Hrvatska. E-pošta: mirjana.radan@gmail.com

*** Željko Rakošec, doktorand, Odjel za kulturologiju, Sveučilišta Josipa Jurja Strossmayera u Osijeku. Adresa: Trg Svetog Trojstva 3, 31000 Osijek, Hrvatska. E-pošta: rakosec@gmail.com 
je plodnost ograničenog vijeka, stavljana je na prvo mjesto ispred svih drugih prioriteta, uz izbjegavanje opasnosti vezanih za njezino narušavanje. Ozračje zasnivanja obitelji zahvaćalo je mladost gradova i sela uz ravnopravnu potporu i doprinos svih. O tome je ovisio pojam sretne obiteljske i društvene zajednice (Orešković i Budak, 1995).

\section{1. Širi kontekst}

$\mathrm{S}$ vremenom je deagrarizacijom, deruralizacijom te industrijalizacijom i urbanizacijom oslabila stabilnost obiteljske zajednice, zbog čega obitelj gubi svoj tradicionalni izgled. »Procesi deagrarizacije u Hrvatskoj proteklih su desetljeća bili bitno brži od procesa industrijalizacije. Tako su sela stanovništvom uglavnom opustjela (bijeg sa sela), gradovi su postali prenapučeni, dok se znatan višak nezaposlenog poljoprivrednog stanovništva iselio iz Hrvatske u zapadnoeuropske i prekooceanske zemlje « (Živić, 2003, 59). Ovim se radom želi ukazati na bitan utjecaj netradicionalnog načina obiteljskog života na plodnost pojedinaca, odnosno posljedično na smanjenu plodnost čitavog naroda. Slična se demografska kretanja događaju i u ostalim europskim zemljama (Sobotka i Beaujouan, 2018; Veljović, 2017). Preoblikovanje tradicionalnog obiteljskog života prvo je započelo u sedamdesetim godinama 20. stoljeća u razvijenim zemljama zapadne Europe, Sjedinjenim Američkim Državama, Australiji, Japanu i Kanadi, da bi tijekom dvadesetak godina postupno prešlo na srednju, istočnu i južnu Europu. Radi utvrđivanja i vrednovanja uzroka (primjerice ekonomski) takvih promjena učinjene su mnoge analize (Matysiak i dr., 2018). Navedene zemlje raznovrsno tumače istu problematiku odgode rađanja za kasne fertilne godine. Matisyak i suradnici smatraju da ekonomski uzroci poput recesije, pada zaposlenosti i nezaposlenosti, pogađaju veći dio Europe. Ali time ne može objasniti pad nataliteta i odgodu rađanja u sjevernoj Europi, prvenstveno u Ujedinjenom Kraljevstvu i Irskoj, gdje nezaposlenost ipak nije bila glavni indikator pojave odgode rađanja.

Prema difuzionističkoj teoriji ${ }^{1}$ pad plodnosti nastao je kao rezultat širenja difuzije novih stavova i ideja prema vrijednosti i troškovima djece u novim okolnostima koje su se pojavile. Također, radi prihvaćanja i difuzije novih znanja, te proizašlih stavova, o tehnikama kontrole rađanja (Vitali i Billari, 2015).

Zeman i suradnici vide problem u brzoj promjeni društvene i gospodarske situacije u južnoj Europi 1960-tih, gdje je omogućena široka upotreba kontracepcije te promjena načina života žene, koja je sada zaposlena, u nefleksibilnim sustavima (Zeman i dr., 2018). To prvenstveno utječe na smanjenje rađanja trećeg i četvrtog, potom i drugog djeteta. Slijedi odgoda rađanja prvog djeteta, zbog još većeg pogoršanja opće situacije. Konačno najsveobuhvatnije djeluje razmišljanje Mills i suradnika iz Nizozemske s obzirom na to da kombinira uzroke. Prema

1 »Teorija kulturne promjene prema kojoj se elementi jedne kulture kulturnim dodirom šire $\mathrm{u}$ drugu. Vrelo definicije: Nanda, S.; Warms, L. R. Culturalanthropology. Ninthedition. Belmont USA: ThomsonWadsworth, 2007., 107« (Sujoldžić, 2015, s. v. difuzionizam). 
njihovim tumačenjima efikasna kontracepcija koja se na tržištu pojavila 1960-tih omogućila je ženi odgodu rađanja u vrijeme koje je povoljno za nju. Pri tome ženama se otvorila mogućnost edukacije, zapošljavanja, karijere i dodatne zarade, što rezultira masovnom odgodom rađanja u Europi i drugdje (Mills i dr., 2011).

\subsection{Plodnost}

Definicija plodnosti ili fekunditeta je sposobnost para u ostvarivanju trudnoće promatrane u mjesec dana, odnosno po ciklusu žene (oko 28 dana). Kod parova u optimalnoj reproduktivnoj dobi ona iznosi 20-30\%, što znači da i do $80 \%$ parova u prvoj godini postižu trudnoću. Prema Svjetskoj zdravstvenoj organizaciji (SZO) fekunditet je optimalan između 20. i 27. godine života (Šimunić i dr., 2012). To je optimalna reproduktivna dob. Poslije opada oko $10 \%$ godišnje, što nakon nekoliko godina postaje bitna razlika.

\subsection{Neplodnost}

Izostanak kliničke trudnoće nakon 12 ili više mjeseci redovnih nezaštićenih spolnih odnosa označava pravu neplodnost ili neplodnost u užem smislu (Zegers-Hochschild i dr., 2009). Općenito se smatra da je neplodnih parova oko 15-17\%, od toga po jedna trećina uzroka su ženskog, muškog i kombiniranog uzroka. Učestalost neplodnosti u optimalnoj reproduktivnoj dobi je niska, oko 4\%. Sa starenjem, nakon 27. godine života naglo raste (Šimunić i dr., 2012). Nakon 40. godine života $29 \%$ žena je neplodno (Šimunić i dr., 2001). Točna procjena rasta neplodnosti sa starenjem i nije moguća, s obzirom na to da već godinama traju fluktuacije stanovništva, demografske promjene i iseljavanje. Zadnja šira statistička obrada rađena je 2007. godine, a od tada su se dogodile bitne izmjene u sastavu reproduktivne populacije. To znači da bi zaključci o postotku neplodnih parova starije reproduktivne životne dobi mogli biti i puno veći, jer su se i okolnosti bitno promijenile.

\subsection{Manipulacije s plodnošću}

Trenutkom neprihvaćanja koncepta o neraskidivosti između bračnog čina i rađanja, koje propisuje Kongregacija za nauk vjere, a opisan je u naputku o poštivanju ljudskog života u nastanku i o dostojanstvu rađanja Donum Vitae (DV), objavljenom 1987 godine (str. 34-45), u bračnom činu nastaje raskid između ljubavi-spolnosti i rađanja- reprodukcije. Time je s jedne strane omogućena kontracepcija, a i različite tehnike pomognute oplodnje in vitro (u epruveti) s druge strane. Manipulacija ženskom plodnošću sastoji se u korištenju različitih sredstava za sprječavanje trudnoće te raznih oblika pomognute oplodnje. Više od pedeset godina razvijaju se metode kontracepcije poput hormonskih pilula te naprava za sprječavanje i razvoj trudnoća. Također se razvijaju i sve se više usavršavaju in vitro metode pomognute oplodnje. Primjena hormonske kontracepcije tijekom godina poprima sve veću važnost. Sedamdesetih godina 20. stoljeća uglavnom su ju koristile udane žene koje su ispunile plan rađanja. Devedesetih godina sve više 
ju koriste neudane mlade žene koje ne žele zasnivati obitelji. Uočivši promjenu u motivima dolaska žena u ginekološku ordinaciju, a s ciljem razrješenja nastalih promjena, 2002. učinjena je obrada podataka uzetih iz kartona žena jedne hrvatske ginekološke ambulante u sjevernom dijelu Hrvatske. S obzirom na to da su 1991. ginekolozi dogovorno prestali raditi abortuse, ta se godina smatra prijelomnom. Pretpostavilo se kako će takva odluka bitno utjecati na daljnje motive posjeta ordinaciji. Podatci su obrađeni, a dokumentirani rezultati objavljeni su na Svjetskom kongresu katoličkih ginekologa u Rimu 2001. godine (Šperanda i dr., 2001). Do 1991. najčešće su dolazile žene starije od 40 godina radi kontrole zdravlja, dijagnostike tumora, a tek potom mlađe žene radi dijagnostike trudnoće i pobačaja. Nakon 1991. motivi se mijenjaju, dolaze uglavnom žene mlađe životne dobi radi dijagnostike trudnoće, ugradnje spirale i uzimanja kontracepcije. Daljom kompleksnom analizom podataka uočeno je da se motivi dolaska žena zapravo nisu promijenili. Postotak pobačaja pada, ali raste „rana dijagnostika trudnoće“ (kako bi se drugdje pobacilo), kao i ugradnja spirale i uzimanje kontracepcijske pilule (radi sprječavanja trudnoće). Uočeno je da žene u promatranom području jednostavno ne žele rađati, jednako kao i u Europi, bilo istočnoj ili zapadnoj. Isto tako, prekid obavljanja pobačaja ih ne može spriječiti u tome da na drugi način ostvare svoju namjeru, to jest da nemaju djece. Postavlja se pitanje: Kakva je situacija danas, nakon 18 godina? Nikakav se preokret u stavu prema obitelji nije dogodio. Štoviše, stihijski je rastao kontracepcijski mentalitet, odnosno anti-obiteljski stav koji ne prestaje s hormonskom pilulom i abortusima.

\subsection{Odgoda radanja}

Stvoreni su uvjeti za odgodu rađanja u vrijeme najbolje plodnosti iz veoma različitih razloga i pobuda. Otvara se prostor za odgodu bračnog života i rađanja „za neka bolja vremena“. Srednje školovanje, visoko obrazovanje, zapošljavanje, dodatne edukacije te angažiranost u poslu uz današnji urbani način življenja sve to poručuje mladima da niti imaju vremena niti smiju razmišljati o obitelji, jer će im ona odvući prijeko potrebnu pozornost, što će rezultirati poslovnim neuspjehom. Nezaposleni mladi razmišljaju slično i ostvaruju sličan neuspjeh. Budući da ne uživaju potreban standard, boje se osnovati obitelj (Bratti i Cavalli, 2014). Znajući da spolno sazrijevanje započinje negdje između 12. i 15. godine života, a biološka spolna zrelost postiže se između 18. i 20. godine, onda je vrijeme preostalo do braka vrijeme odricanja od braka i onoga što brak nosi, a to je prvenstveno očinstvo i majčinstvo. Koju god tehniku za održavanje takvoga statusa — odricanja od braka — mladi koristili u svojim vezama, postižu jednaki rezultat, strah od djeteta, zatim strah od obitelji. Pod „tehnikama“ misli se na kontracepciju, odnosno sve oblike spolnih odnosa u kojima je uključena zaštita od trudnoća. Godinama i sustavno mladi žive u uvjerenju da trebaju izbjegavati mogućnost zasnivanja obitelji i rađanja djece. S vremenom im to postaje navika i stav koji se više ne spominje. Umjesto da stvaraju prostor za obiteljski život, oni ga izbjegavaju, a potom ga više i ne žele jer im je stran. Takvo razmišljanje potpomažu i mnogobrojne medijske stranice (tisak, Internet), koje umanjuju važnost 
starenja za plodnost, obećavajući različite oblike pomoći kad god im zatreba. Nasuprot tomu, obećavani uspjeh, standard življenja kojemu teže, čini se kao da im izmiče, nikako da ga postignu. Misle kako im treba još samo malo truda, odricanja od obitelji i postići će ga. Ako i postoji razmišljanje o obitelji i djeci, ono se ostavlja za kasnije, za „bolja vremena“. Kako se primiču granične godine pogodne za rađanje, zavaravaju se kako će uz tolike postojeće tehnike pomognute oplodnje nekako i postići začeće. Istovremeno prikazuju se mogućnosti zanošenja koje to zapravo više i nisu.

\subsection{Anti-obiteljska atmosfera}

Stvorena je anti-obiteljska atmosfera. Konačno ti „mladi“ više i ne znaju organizirati život u bračnoj zajednici, jer naučeni su na samostalan, često komotan život bez obiteljskih obveza. Raskorak između optimalnog vremena za rađanje od 20. do 27. godine i stvarnog okretanja rađanju sve je veći (Burkimsher, 2015). Danas prevladava shvaćanje da je optimalno vrijeme rađanja oko 35. godine, pa čak i kasnije. Tijekom kolovoza 2017. godine objavljena je vijest kako je prvi puta u povijesti zemlje rodilo $50 \%$ više žena starijih od 30 godina. Prema izvještaju Hrvatskog zavoda za javno zdravstvo još tijekom 2016. rodilo je 54,09\% žena starijih od 30 godina (Rodin i dr., 2017). Uzročno spominju se socijalni i ekonomski faktori, razvodi brakova, kasni brakovi i odgode rađanja. Posljedično smanjeni broj djece postaje normalan (Zsembik i Gui, 2016). Brak bez djece je uobičajen. Rađa se jedno ili ni jedno dijete u obitelji. (Koert i Daniluk, 2017). Raspoloženje prema obitelji i djeci prekriveno je mnoštvom izlika koje djeluju važnije i bitnije u životu ovog trenutka (Koprek, 2015). Stvoren je anti-obiteljski obrazac razmišljanja, tako da je pitanje, kada bi se i ostvarili razlozi navedeni kao uzroci odgode rađanja (posao, zarade, stambeno pitanje), bi li se situacija promijenila. Stvoren je kontracepcijski mentalitet. Rezultat svega je niska plodnost te porast neplodnosti parova starije reproduktivne životne dobi. Točna učestalost neplodnosti po dobi se ne zna, ali svakako je u značajnom porastu, jer je registrirano svake godine $10 \%$ više postupaka pomognute oplodnje. Maksimalna plodnost žene je negdje do 24. godine života, a potom počinje blago padati, da bi poslije 26. ili 27. počela naglo opadati. Od 32. do 35. godine ona iznosi tek nešto više od $22 \%$ od maksimalne plodnosti, u biološki optimalnom vremenu. S tim potencijalom danas ulaze navodni mladi u brak. Istovremeno postotak spontanih pobačaja raste s godinama starosti, naglo nakon 32. godine života (Šimunić i dr., 2012). Poznato je od ranije da rađanje u starijoj životnoj dobi posljedično uzrokuje moguće metaboličke bolesti djeteta koje je imala majka, kao primjerice dijabetes i pretilost (Dumić i Špehar, 2009). Kod muškaraca s godinama opada plodnost radi fragmentacije kromosoma u spermatidama, što može dovesti i do neplodnosti (Belloc, 2014). S razvojem genetske dijagnostike, pronalaze se uzročnici neplodnosti u genskim abnormalnostima tipa mikrodelecija na Y kromosomu, koji izazivaju oligoastenospermiju, astenozoospermiju u muškaraca, ili intrauterino odumiranje plodova, koji se mogu povezati sa starenjem (Miyamoto i dr., 2017). Pri tome jednak problem imaju i parovi koji koriste in vitro tehnike 
(IVF), s obzirom na to da je odumiranje genski programirano. Žene koje kasno otkriju probleme oko zanošenja vrlo često zbog složenih uzroka ostaju neplodne, te im ni jedna od suvremenih tehnika ne može pomoći. Tada razmišljaju o zamjenskom majčinstvu, koje radi etičkih, pravnih i društvenih kompleksnosti s brojnim negativnim učincima na obitelj i širu zajednicu, nije dozvoljeno u Republici Hrvatskoj (Radan, 2018).

\subsection{Anti-obiteljski mentalitet}

Promatrajući razvoj anti-obiteljskog mentaliteta od 1971., tijekom 25 godina pa sve do danas, sve više obitelji, kao i čitavo društvo ostaju bez djece. U početku su kontracepciju uzimale udane žene koje su ispunile plan rađanja, te nisu više htjele imati djecu, niti vršiti abortuse. Potom mlade neudane žene, koje su kontracepciju uzimale kratko vrijeme prije braka. Slijedi odgoda rađanja do sve starijih reproduktivnih godina, što je postepeno dovelo do toga da se rađanje danas gotovo stapa sa pred-menopauzom. Žene koriste tek vrlo kratko životno razdoblje za planiranje obitelji, koje se odvija u neprikladno vrijeme. Naime, tada je zbog visoke dobi trudnoća često rizična, kako za zdravlje žene, tako i za nerođeno dijete (Balasch i Gratacós, 2011). Dakle, u pitanju je bitno povišen rizik od neplodnosti i/ili neuspjelih trudnoća.

\section{Općedruštveni problem}

Zbog odgode rađanja i ulaska u brak u srednjim i starijim reproduktivnim godinama te komplikacija koje iz toga proizlaze, neplodnost danas nije samo medicinski, nego ponajprije općedruštveni problem (Pötzsch, 2016).

Kako bi se razumio proces plodnosti kod mladog bračnog para, vrlo je važno odgovoriti na pitanje: Očekuju li žene i muškarci trudnoću ili je žele izbjeći? Takvim stavovima zauzima se anti-obiteljski ili pro-obiteljski mentalitet, što je vrlo važno u duhovnom i emocionalnom, ali i somatskom pripremanju parova za trudnoću (Hilgers, 2004).

\subsection{Pro-obiteljsko stajalište}

Bitno je zadržati pro-obiteljsko stajalište, odnosno ne odvajati spolnost od reprodukcije, što zapravo čini ispravno stajalište o obiteljskom životu. Uvažavanjem tih jednostavnih uputa poštuje se obitelj, dijete, životno okružje. Bračni se par priprema na dijete u pravo reproduktivno vrijeme, kada je rizik za nastajanje neplodnosti minimalan i iznosi tek oko $4 \%$.

Nužno je osvijestiti kako demografi godinama vrlo ozbiljno upozoravaju o iznimno lošoj demografskoj situaciji u Hrvatskoj. Zadnjih godina zapravo javno i otvoreno govore o demografskom slomu. 


\subsection{Izumiranje}

Mladi koji čine reproduktivni depo Hrvatske masovno iseljavaju. Hrvati su i ranije proživljavali teška razdoblja (ratovi, odlazak muškaraca na rad u inozemstvo, katkada i masovno u siromašnim godinama). Razlika je u tome što se do sada nikada tako nisu masovno iseljavale cijele obitelji (muškarci, žene, djeca). Također, ostatak naroda nikada do sada nije bio tako zastrašivan mogućim lošim događanjima i bezperspektivnošću kao danas. Iseljavanje poprima zastrašujuće okvire, osobito uzme li se u obzir da iseljavaju cijele mlade obitelji s djecom. Time se gubi ne samo sadašnji mladi reproduktivno sposobni naraštaj, nego i budući — djeca, kojih više nema u Republici Hrvatskoj (Akrap, 2015).

\subsection{Demografski slom Hrvatske i Europe}

Slične promjene u društvu događaju se i diljem Europe. Ostaju starije generacije koje su izgubile reproduktivnu sposobnost ili su pri njezinu kraju. U 51 zemlji svijeta predviđa se pad broja stanovnika do 2050. godine (Coleman, 2014). Oko $46 \%$ svjetskog stanovništva živi u zemljama s niskom razinom plodnosti, gdje žene imaju manje od 2,1 djeteta (cijela Europa i Sjeverna Amerika, kao i mnoge zemlje u Aziji, Latinskoj Americi i na Karibima) (United Nations, 2015, 8-9). S padom stanovništva za 15-17\% Hrvatska se nalazi na visokom petom mjestu u svijetu. Prema izvješću Ureda Ujedinjenih naroda za ekonomska i socijalna pitanja (DESA), osim Hrvatske od europskih država u toj skupini nalaze se još Bugarska, Latvija, Litva, Poljska, Moldavija, Rumunjska, Srbija i Ukrajina. Od ostalih država svijeta još Djevičanski Otoci (United Nations, 2017). Podsjetimo se da totalna stopa fertiliteta za jednostavnu reprodukciju iznosi 2,1. Navedeno znači da se s tom stopom populacija sljedeće generacije brojčano ne bi mijenjala. Stopa fertiliteta za Hrvatsku iznosi 1,48. Ostale države Europe su naizgled u nešto boljem položaju, jer su useljavanjem dobili i populaciju djece. U Njemačkoj je stanje zapravo jednako dramatično: prema istraživanju, čak 36\% djece mlađe od 5 godina rođeno je od roditelja — imigranata. Međutim, bez imigranata broj stanovnika u Njemačkoj smanjit će se za 18\%, a u Italiji za 16\% (Vitali i Billari, 2015). U zapadnoj, sjevernoj i južnoj Europi, kao i u Hrvatskoj, žene rađaju prvo dijete u dobi starijoj od 30 godina u oko 50\% slučajeva, sa španjolskom na čelu s oko $60 \%$ (Schmidt i dr., 2012).

\subsection{Izvanredno stanje}

Vrh države prepoznaje težinu problema i poziva na uzbunu na najvišem nivou. S obzirom na to da je demografija pitanje svih pitanja i s obzirom na izvanredno stanje, potrebno je poduzeti i izvanredne mjere. Na razini izvršne vlasti demografska revitalizacija mora dobiti najviši mogući prioritet, koji će omogućiti jedinstveno i usklađeno djelovanje državnih tijela, znanstvene zajednice i udruga koje se bave demografskom obnovom. Zemlja s puno resursa pitke vode, tolikim prirodnim datostima, na relativno malom arealu velika biološka raznolikost. Zemlja autentičnog razvoja, identiteta, kulture, prevažnog geopolitičkog i geo- 
strateškog položaja je dragocjena. Pogled u nedavnu prošlost i na njezine žitelje obvezuje nas da ju čuvamo na svim razinama, osobito s obzirom na sve one koji su budućim generacijama omogućili slobodnu zemlju koja bi svakomu svojemu stanovniku trebala osigurati dostojanstven život.

\section{5. Život u Hrvatskoj}

Činjenica je da život u Hrvatskoj nije tako loš. To pokazuje i analiza Unicefa učinjena 2012. o tome koje su najbolje zemlje u Europi za zasnivanje obitelji te podizanje i odgoj djece. Istraživanje je pokazalo da su najbolje zemlje Danska, Finska, Norveška i Švicarska, a Hrvatska je na dvanaestom mjestu (UNICEF, 2016, 14-15). S obzirom na to da su u obzir uzeti mnogobrojni parametri, može se sa sigurnošću zaključiti kako Hrvatska ima dobre uvjete za podizanje i odgoj djece. Još uvijek njeguje tradicionalne obiteljske i društvene vrjednote. Poštuje ljudsku narav, njezinu raznolikost i darovitost. Pitanje glasi: Tko nas to uvjerava u suprotno? Tko stvara tako uvjerljivu anti-obiteljsku klimu? (Zeman i dr., 2018).

\section{Zaključak}

Moramo ponovno usvojiti obiteljski obrazac razmišljanja i ponašanja koji smo tijekom posljednja tri desetljeća opravdano ili neopravdano zapustili. Kako bi se promijenio negativan stav i mentalitet prema obitelji i djeci, to djelovanje obuhvaća pozitivne promjene na više razina (odgoj, edukacija, primjer u obitelji, školi i vjerskoj zajednici).

Stoga bi bilo potrebno:

1. kod mladih sustavno razvijati zahvalnost za naslijeđena spolna obilježja, što ih polako usmjerava prema roditeljstvu, odnosno prema ulozi oca i majke u odrasloj dobi;

2. omogućiti mladima upoznavanje i prihvaćanja vlastitosti muške, odnosno ženske spolnosti uočavanjem, uvažavanjem i poštivanjem različitosti spolova;

3. stvarati obiteljsko ozračje koje omogućava pravilan rast i sazrijevanje, osobito spolno sazrijevanje;

4. skladnim i vjernim življenjem braka, vlastitim primjerom pokazati djeci kako je brak važan, potreban, koristan i siguran oblik zajedničkog života;

5. educirati mlade o važnosti pravodobnog zasnivanja obitelji; buditi svijest o rizicima odgode rađanja; kompliciranje zdravstvenog stanja zbog veće mogućnosti pobolijevanja uopće, osobito zbog oštećenja reproduktivnog zdravlja (miomi, ciste, upale i sl.) razmjerno kronološkoj i biološkoj starosti;

6. educirati mlade o obiteljskim vrijednostima, osvješćivanjem zaboravljenih obiteljskih vrjednota (povezivanje i razgraničavanje uloge oca, uloge majke, mogući suživot više generacija te sudjelovanje djece u obiteljskim poslovima u obliku, količini i odgovornosti koja je primjerena njihovoj dobi i razvoju); 
7. organizirati društvenu strukturu za upoznavanje parova s najčešćom problematikom (komunikacijske vještine, okupljanja mladih, druženja, trijaža i dijagnostika mogućih uzroka neplodnosti);

8. prevencija, promjena stila i načina života na bolje (sport, prehrana, uklanjanje ovisnosti);

9. stvarati društveno pogodno ozračje za osnivanje obitelji (bolje plaće, radna mjesta, stanovi, dovoljno vremena za obiteljska okupljanja, poštivanje neradnih blagdana i nedjelja i dr.);

10. $\mathrm{u}$ institucionalnom odgoju mora postojati atmosfera koja će mladima dati obiteljsku perspektivu i usađivati im obiteljske vrijednosti, bez obzira što su mladi skloni negirati opće društvene i moralne vrijednosti, koje, zatreba li, moraju biti dostupne i sadržajne;

11. važno je postići sinergiju i komplementarnost odgojnog roditeljskog utjecaja na vlastitu djecu (otac i majka trebaju biti jedinstveni u davanju ispravnih informacija potrebnih za pravilan rast i razvoj njihove djece, moraju biti ustrajni, uporni, dosljedni u njihovu provođenju);

12. neophodna je sinergija i komplementarnost na društvenoj razini između obitelji kao osnovne funkcionalne jedinice društva i samog društva: tako razne društvene strukture (crkva, škola, različite odgojne ustanove), nastavljaju i dalje razvijaju zdrav odgoj koji su djeca već primila u svojim obiteljima, što se ostvaruje praćenjem mladih, konzultacijom s roditeljima uz pravovremeno i učinkovito rješavanje mogućih, često nepredvidivih situacija.

\section{Literatura:}

Akrap, Anđelko (2015). Demografski slom Hrvatske: Hrvatska do 2051. Bogoslovska smotra, 85(3), 855-881.

Balasch, Juan; Gratacós, Eduard (2011). Delayed Childbearing: Effects on Fertility and the Outcome of Pregnancy. Fetal Diagnosis and Therapy, 29, 263-273.

Bratti, Massimiliano; Cavalli, Laura (2014). Delayed First Birth and New Mothers' Labor Market Outcomes: Evidence from Biological Fertility Shocks. European Journal of Population, 30(1), 35-63.

Burkimsher, Marion (2015). Europe-wide fertility trends since the 1990s: Turning the corner from declining first birth rates. Demographic Research, 32, 621-656.

Coleman, David (2014). The death of Europe has been postponed. U: Nico van Nimwegen (ur.), The Resourceful Demographer: Liber Amicorum (str 73-78). Hag: Ando.

Dumić, Miroslav; Špehar Uroić, Anita (2009). Djeca majki s dijabetesom. U: Josip elmiš, Marina Ivanišević, Željko Metelko i suradnici, Dijabetes u žena (str. 390-398). Zagreb: Medicinska naklada.

DV. Donum vitae. Kongregacija za nauk vjere, Donum Vitae: Dar života: Naputak o poštivanju ljudskog života u nastanku i o dostojanstvu rađanja. Zagreb: Kršćanska sadašnjost, 1987.

Hilgers, Thomas W. (2004). Medical and Surgical Practice of NaProTECHNOLOGY. Omaha, Nebraska: Pope Paul VI Institute Press. 
Koert, Emily; Daniluk, Judith C. (2017). When time runsout: reconciling permanent childlessness after delayed child bearing. Journal of Reproductive and Infant Psychology, 35(4), 342-352.

Koprek, Ivan (2015). Razarajući čimbenici braka i obitelji. Bogoslovska smotra, 85(3), 759-778.

Mills, Melinda; Rindfuss, Ronald; McDonald, Peter; Velde, Egbert (2011). Why do people postpone parenthood? Human Reproduction Update, 17(6), 848-860.

Miyamoto, Toshinobu; Minase, Gaku; Takeshi, Shin; Ueda, Hiroto; Sengoku, Kazuo (2017). Human Male Infertility and Its Genetic Causes. Reproductive medicine and biology, 16(2), 81-88.

Pötzsch, Olga (2016). Fertility in Germany before and after the 2011 Census: Still no Trend Reversal in Sight. Comparative Population Studies, 41(1) 87-118.

Matysiak, Anna; Sobotka, Tomaš; Vignoli, Daniele (2018). The Great Recession and Fertility in Europe: A Sub-National Analysis. Beč: Vienna Institute of Demography.

Orešković, Stjepan; Budak, Antun (1995). Hrvatska obitelj: demografske, epidemiološke i zdravstvene tranzicije i novi sustav zdravstvene zaštite. Društvena istraživanja, 4(4), 487-502.

Radan, Mirjana (2018). Zamjensko majčinstvo: Bioetička prosudba. Zagreb: Centar za bioetiku - Filozofsko-teološki institut Družbe Isusove

Rodin, Urelija, Draušnik, Željka, Cerovečki, Ivan (2017). Porodi u zdravstvenim ustanovama u Hrvatskoj 2016. godine. Zagreb: Hrvatski zavod za javno zdravstvo.

Schmidt, Lone; Sobotka, Tomáś; Bentzen, J. G.; Nyboe Andersen, A. (2012). Demographic and Medical Consequences of the Postponement of Parenthood. Human Reproduction Update, 18(1), 29-43.

Sobotka, Tomáš; Beaujouan, Éva (2018). Late Motherhood in Low-Fertility Countries: Reproductive Intentions, Trends and Consequences. U: Dominik Stoop (ur.), Preventing Age Related Fertility Loss (str. 11-29). Basel: Springer International Publishing Switzerland.

Sujoldžić, Anita (ur.) (2015). Hrvatsko antropološko nazivlje. Zagreb: Institut za hrvatski jezik i jezikoslovlje.

Šimunić, Velimir; Jeren, Lana; Suchanek, Ernest (2001). Izvantjelesna oplodnja i ostale pomognute oplodnje. Gynaecologia et perinatologia, 10(1), 64-69.

Šimunić, Velimir i sur. (2012). Reprodukcijska endokrinologija i neplodnost: Medicinski pomognuta oplodnja: IVF. Zagreb: Hrvatski liječnički zbor — Hrvatsko društvo za ginekološku endokrinologiju i humanu reprodukciju — Školska knjiga.

Šperanda, Žarko; Richter, Branimir; Pozaić, Valentin (2001). Motives for Visiting a Gynaecological Practice in the Period of 25 Years. International Meeting of Catholic Obstetricians and Gynaecologists, Rome, June 17-20, 2001. URL: http://www.fiamc. org/fiamc/03events/0110gyneco/gyntexts/speranda/speranda.htm 06.05.2018.

UNICEF, Office of Research (2016). Fairness for Children: A league table of inequality in child well-being in rich countries: Innocenti Report Card 13. Firenca: UNICEF Office of Research - Innocenti.

United Nations, Department of Economic and Social Affairs, Population Division (2015). World Fertility Patterns 2015: Data Booklet. New York: United Nations.

United Nations, Department of Economic and Social Affairs, Population Division (2017). World Population Prospects: The 2017 Revision, DVD Edition. New York: United Nations.

Veljović, Radmila (2017). Odlaganje rađanja — referentni okvir motivacionog sistema. Demografija, 14, 47-63. 
Vitali, Agnese; Billari, Francesco C. (2015). Changing Determinants of Low Fertility and Diffusion: A Spatial Analysis for Italy. Population, Space and Place. DOI: 10.1002/ psp.1998

Zegers-Hochschild, F.; Adamson, G. D.; Mouzon, J. de; Ishihara, O.; Mansour, R.; Nygren, K.; Sullivan, E.; Vanderpoel, S. (2009). International Committee for Monitoring Assisted Reproductive Technology (ICMART) and the World Health Organization (WHO) revised glossary of ART terminology, 2009. Fertility and sterility, 92(5), $1520-1522$.

Zeman, Krystof; Beaujouan, Eva; Brzozowska, Zuzanna; Sobotka, Tomas (2018). Cohort fertility decline in low fertility countries: Decomposition using parity progression ratios. Demographic Research, 38(25), 651-690.

Zsembik, Barbara; Gui, Tianhan (2016). Delayed Childbearing. U: Constance L. Shehan (ur.), The Wiley Blackwell Encyclopedia of Family Studies. S. 1.: John Wiley \& Sons.

Živić, Dražen (2003). Demografski okvir i razvoj obiteljske strukture stanovništva Hrvatske 1971-2001. Revija za sociologiju, 34(1-2), 57-73.

\title{
The Demographic Collapse of Croatia and Europe
}

\author{
Žarko Šperanda*, Mirjana Radan**, Željko Rakošec***
}

\section{Summary}

The demographic profile of the family in the Republic of Croatia has changed fundamentally in the last forty years. The harmonious family atmosphere in which care was taken to preserve it from generation to generation and the timeliness of marriage and childbirth are no longer the rule, for deagrarianization and urbanization have caused the family to lose its traditional appearance. When young adults are at the age of optimal biological maturity, the planning of a family is not possible for various reasons, primarily economic in nature. Moreover, it has become acceptable to separate the marriage act from procreation, and this has created a space for the manipulation of fertility. For fifty years or so, various methods of contraception have been developed and are being used, including in vitro fertilization and stem cell storage at the KRIO Institute. Surrogate motherhood is also not a novelty. Contraception enables people to postpone marriage and childbirth even until this is biologically inappropriate, consequently, numerous complications are possible in relation to conception and pregnancy follow-ups, and birth to older primiparae. Whatever technique is used in delaying childbirth, the same effect is achieved in young adults, and that is fear of having a family, fear of having a child. An anti-family atmosphere has been created because of which children are unwanted and marriage without children is normal. A contraceptive mentality has been created. Similar changes are

* Žarko Šperanda, M.Sc., Community Health Centre Slavonski Brod. Address: Borovska 7, 35000 Slav. Brod, Croatia. E-mail: sperandazarko@gmail.com

** Mirjana Radan, Ph.D., County Hospital Čakovec. Address: I.Gorana Kovačića 1 e, 40000 Čakovec, Croatia. E-mail: mirjana.radan@gmail.com

*** Željko Rakošec, Doktorand, Department of Cultural Studies, University of Josip Juraj Strossmayer, Osijek. Address: Trg Svetog Trojstva 3, 31000 Osijek, Croatia.

E-mail: rakosec@gmail.com 
occurring in the majority of European countries, but at various rates, and these are leading us to extinction. It is of vital importance to change thought patterns, to again adopt a pro-family way of thinking since this has been neglected. Young people must be guided at an early age toward building an awareness of the importance of starting a family, producing offspring at the proper time and also maintaining and promoting the family unit as such.

Key words: demographics, decreased fertility, infertility, contraceptive mentality, family attitude 